\title{
Dysmnestic seizure（記憶障害発作）を訴えた
} 72 例のてんかん患者の臨床的検討

一自律神経性前兆との比較を中心として一

兼本浩祐* 馬屋原 健* 山田広和** 河合逸雄*

\section{Dysmnestic Seizures-A Special Attention to the Comparison with Patients suffering from Autonomic Seizures}

\begin{abstract}
要旨 : 本院にてんかんを主訴として来院し, 単純部分発作を示した 563 人の患者から dysmnestic seizure（記憶障害発作）を報告した72人の患者を対象として選択した。その内訳 は，既知感が 34 人，現実感喪失が $29 人 ，$ 追想が 20 人であった。自律神経性前兆を示す患者 群との比較に扔いて, dysmnestic seizure を持った患者は，(1) 発症年路が高い，(2) 不 安発作の合併率が高い，(3) 複雑熱性痤攣の既往歴が少ないという諸点が統計的に有意な 差異を示していた。Dreamy stateや intellectual aura などといった伝統的な述語と国際 分類の dysmnestic seizure との関係を論ずるとともに, 導きだされた結果に対して若干の 文献的考察を加觉た。
\end{abstract}

てんかん研究 $1993 ; 11: 101-109$

Key Words: dysmnestic seizure, autonomic seizure, complex febrile seizure, age at onset, anxiety aura.

（受付：1992年 9 月 11 日, 第 1 回訂正 : 1992年11月 16 日, 第 2 回訂正 : 1992年12月 2 日, 受 理：1992年12月 3 日)

\section{はじめに}

Bergson ${ }^{1)}$ は，「物質と記憶」といらその著書の 中で, 記憶を, 身体的記憶と精神的な思い出に分 けた。例えば, “aimer”といらフランス語の単語 を記憶しょらとする時に, “aimer”が「愛する」 という日本語に当たるという反復によって身につ けられた知識は前者に属するのに対して, “aimer” といら単語を始めて聞いたのは自分が高校 1 年の 夏で, 失恋の痛手から映画館に入りびたっていた 時だったといったその単語を覚えた時の状況の記
憶は後者に属する。こういった記憶の二分法は， 最近, 神経心理学の分野に沶いて沉用されている いわゆる意味記憶とェピソード 記憶の二分法と 少なからぬ部分において共通点を持っており， Bergson の記憶の二分法は現在の神経心理学的観 点からみてもなお，その命脈を失ってはいな い。二番目の型の記憶を Bergson は人に特有のも のであると考㝋たが，時間の刻印を色濃く帯びた 二番目の型の 記憶の 錯䛊の一つの例として, Bergsonは, 「今, 起こっていることが, 既に体験 されてしまったことの再現であるかのように感じ

* 国立療養所宇多野病院関西てんかんセンター [干616 京都市右京区鳴滰音戸山町 8]

Kousuke Kanemoto, Ken Mayahara, Itsuo Kawai Utano National Hospital, Kansai Regional Epilepsy Center

** 同 ケースワーカー

Case Worker, Hirokazu Yamada 
る錯覚」，すなわち，既視体験を挙げている。 1981年のてんかん発作の国際分類 ${ }^{5)}$ で，精神症 状を示寸単純部分発作は，6つに大別されたが， その一つに dysmnestic seizure (記憶障害発作) が挙げられている。既視体験, 未視体験（慣れた ものであるはずなのに始めて見る感じがするこ と), 強制的追想（過去の情景が現在の質を帯び て出現すること）などがその具体的内容であるこ とを考えると ${ }^{5,20)}$, dysmnestic seizure は, Bergson の二番目の型の記憶の発作であると捉えることも できよう。Dysmnestic seizure が，てんかんの臨 床表現として存在することは, 既に十九世紀半ば 過ぎには知られて抢り, intellectuall aura の一 形態として記載されている11,13)。いわばエピソー ド記憶の陽性症状ともいえる dysmnestic seizure の検討が，てんかん学からの記憶論への寄与のた めの欠くべからざる一端であることは, 最近の Gloor ${ }^{8)}$ の総説を待つまでもなく明らかであるが, その症候論が本来持っている意義と比して, 既視 体験やその類縁体験を主題とした論文は本邦に打 いては, 僅かに扇谷ら 27)の dreamy state に関す る論文があるに過ぎない。

本検討に扔いては, dysmnestic seizure を示し た多数のてんかん患者を集積し，その症候論的位 置を再検討するとともに，自律神経性前兆を示す 患者との比較を通して, dysmnestic seizure を示 す患者の特徵を浮き彫りにすることを試みた。

\section{対象と方法}

1984年 5 月から1992年 5 月までに関西てんかん センターに来院した 3,012 人のてんかん患者のう らから, dysmnestic seizure を前兆として報告し た患者を抽出したところ，72人に扔いて該当する 訴えが認められた。

Dysmnestic seizure の特徵を検討するために, 本報告に扣いては, 自律神経性前兆を訴える患者 群を対照例として選択したが，具体的には，自律 神経性前兆を合併せず dysmnestic seizure を示す 患者群(62人) (以下 DM 群) と, dysmnestic seizure を合併せず自律神経性前兆を持つ患者群（83人） (以下 AU 群) とを比較した。本検討においては， 自律神経性発作は, 上腹部不快感を代表とする体
Table 1 Contents of dysmnestic seizures $(n=72)$

$\begin{array}{cc}\text { alteration of familiarity } & \\ \text { deja vecu } & 34 \\ \text { derealization } & 29 \\ \text { reminiscence } & 20\end{array}$

軸に沿った左右対称の発作性感覚異常に, 覀心・ 嘔吐，呼吸の変化などを加えたものとした。身体 に拈ける局在が明確でない，漠然と「気分が悪い」 「ボーッとする」といった訴えは，いわゆる EsAura ${ }^{15)}$ などとの弁別が 明膫でないため自律神経 性発作のなかからは除外している。また, 本報告 に扣いては，自己の前兆体験を十分に記述しえな いような症例は自ずから除外されており, 精神遅 滞の記載のあるものは I.Q. 60～70 の軽度の症例 に限られている。

さらに, 本報告では, 中枢神経系の感染症など 他の明らかな原因なく，熱性痤攣が30分以上持続 したか, あるいは, HH 症候群6)を呈したものを 重症熱性痤挙と定義した。

な敃，述語として，以下では，既視体験の代わ りに既知感を用いるが，これは，該当する体験が 視覚のみに限定されては扣らず, 聴覚や時には嗅 覚に及ぶことを考虑に入れてのことである。

\section{結 果}

\section{1. dysmnestic seizure の内容 (Table 1)}

(1) 親近感の変容 (illusion of familiarity) を 訴光たものは 61 人 $(85 \%)$ であり，5ち, 既知感 が 34 人，現実感喪失を含む未知感が 29 人によって 訴えられた。

(2) 既知感のうちで,「次に人がいらことが分 かる」,「これからいわはると思ったことをテレビ などがいっている」など, 自分が予感したことが 実現されていくといら錯覚を抱く場合が 4 例あっ たが，この感じは 3 例において「前にも同じよう なことがあった」という既知感と移行関係にあ り，1例では現実感の喪失を伴っていた。

（3）現実感喪失は，ほとんどが自分を取り巻く その時の状況に対するものであったが, 自我意識 および身体意識に関わる現実感の喪失が報告され た症例も 5 例あった。その 5 例に和いては,「自 
Table 2 Patients with dysmnestic seizure $(n=72)$

\begin{tabular}{|c|c|}
\hline $\operatorname{sex}(m / f)$ & $32 / 40$ \\
\hline age & $25.5 \pm 10.5$ \\
\hline onset & $15.3 \pm 9.2$ \\
\hline M.R. & $7 \%$ \\
\hline paralysis & $6 \%$ \\
\hline complex partial seizure & $71 \%$ \\
\hline oral automatism & $25 \%$ \\
\hline verbal automatism & $14 \%$ \\
\hline tonic clonic seizure & $60 \%$ \\
\hline only during sleep & $11 \%$ \\
\hline
\end{tabular}

M.R.: mental retardation

分の体の現実感がない」といった身体面に限局し た訴觉から，「自分自身を他人の目で見つめてい る」といった自我意識と身体意識の双方にまたが るような訴えを経て，「自分が二人いる」のよう に二重身体験に近いものまで一連の流れが認めら れた。

（4）過去の追想は， 21 人で認められた。

（5）追想の内容は 16 人までが 過去の光景であ り, 何か過去の体験が蘇ってはいるがそれが視覚 的なものかどらか不明なものが 3 人あった。他 に,「以前見た人の顔が思い浮かぶ」といら相貌 に関する追想が 1 例, 「小学校の 時の運動会の臭 いが蘇ってくる」といら臭いの追想が 1 例で認め られた。

（6）複数の光景が走馬灯のように次々と浮から゙ ことを報告した症例が 4 例あったが，このうち， 2 例は過去のどんな光景が次々に思い浮かぶのか を明確に述べることができた。

（7）追想に明確に陰性感情を伴うものは 4 例, 陽性感情を伴うものは 5 例であったが，陽性感情 はいずれも「懐かしい感じ」であった。

（8）追想・親近感の変容のいずれにおいても, 状況ないしは光景がその対象となることが最も多 かったが，3例に特いては考觉や言葉が(「次々 に浮かんで来る考觉が前に考光たことであったよ らな気がする」，「懐かしいような夢をみているよ うな感じの中で言葉では言い表せないいつも同じ 考えが頭に浮かぶ」)，2例に括いては相貌が(「そ の場にいる人の顔が学校時代の昔の同級生の嫌な
Table 3 Possible etiologies of epilepsy

\begin{tabular}{lr}
\hline perinatal troubles & $11(15 \%)$ \\
head trauma & $7(10 \%)$ \\
meningo-encephalitis & $8(11 \%)$ \\
brain tumor & $4(6 \%)$ \\
complex febrile seizure & $4(6 \%)$ \\
\hline febrile seizure & $9(12 \%)$ \\
\hline no possible etiology & $28(39 \%)$ \\
\hline total & $72(100 \%)$ \\
\hline
\end{tabular}

顔に見えてくる」)，1例で既に述べたように臭い が対象となっていた。

（9）発作を誘発する刺激として，3名において 視覚的印象 (白い線が強く印象に残る) が， 1 名 に怙いて嗅覚的印象が強く残ることが挙げられ， 3 名に扣いて人の名前や顔などが思い出せそうで 思いだせない時に発作が起こることがあると報告 されていた。

2. dysmnestic seizure を伴う患者（Table 2)

（1）対象例はすべて局在関連てんかんに分類さ れた。

（2）男性と女性の 比率は， 32 人対 40 人であっ た。

(3) 問診・検査時の平均年蹂は, $25.5 \pm 10.5$ 歳 であった。

（4）発症年齢の平均は， $15.3 \pm 9.2$ 歳であった。

（5）I.Q. 70 以下の精神遅滞を伴ら人の占める 割合は全体の $7 \%$ でった。

（6）麻痺を伴うものは全体の $6 \%$ であったが， 左麻痺が 1 人に対して右麻痺は 3 人であった。

（7）複雑部分発作を有していた患者は， 7 割 （51人）であった。

（8）強直間代発作を有していた患者の割合は 6 割（43人）であった。

（9）強直間代発作を持った患者のうちでこれが 夜間にのみ出現する割合は, 2 割弱 $(8$ 人) であ った。

3. dysmnestic seizure を伴ったてんかんの 推定原因（Table 3)

（1）周産期障害は11人（15\%）において認めら 
Table 4 Interictal EEG findings of dysmnestic seizures

\begin{tabular}{lc}
\hline diffuse spike \& wave complex & 1 \\
temporal spikes or sharp waves & 42 \\
occipital spikes or sharp waves & 4 \\
frontal spikes or sharp waves & 2 \\
other epileptiform discharges & 4 \\
\hline sidedness (left/right) & $20 / 22$ \\
\hline no epieptiform discharge & 20 \\
\hline total & 72 \\
\hline
\end{tabular}

れたが, その内訳は仮死出産が 3 名, 強度の黄 疸, 難産, 早期破水がそれぞれ 2 名, 微弱陣痛, 未熟児出産が 1 名であった。

（2）脳髄膜炎の既往歴は， 8 人 $(11 \%)$ で認め られた。脳髄膜炎の既往歴は 1 名においてのみ細 菌性が疑われたが，他は無菌性であった。

（3） 1 時間以上の意識消失を伴う頭部外傷は, 7 人 $(11 \%)$ 飞打いて認められた。

(4) 脳占拠性病変は 4 例に打いて認められた が，そのうち 1 例は側頭部血管腫であり, 他の 3 例は側頭部クモ膜のう胞であった。

（5）発作が 1 時間以上続いたり，発作後片麻痺 を続発した重症複雑熱性㾏攣の既往歴を持った患 者も 4 例において認められた。

(6) migraine accompagnée が明らかに発作々 因果関係を持っていると思われた症例が 2 例認め られた16)。

（7）熱性痤攣は 9 例， 1 割強の患者に特いて認 められた。

（8）てんかんの原因となり得るような脳疾患の 既往歴の認められなかった患者は28例 $(39 \%)$ で あった。

4. 脳波所見 (Table 4)

（1）全般性棘徐波結合が 1 例（1％）に拈いて 認められた。

（2）側頭部の棘波ないしは鋭波が42例（58\%） に打いて認められた。

（3）後頭部の棘波ないしは鋭波が 4 例（6\%） に扣いて認められた。

（4）前頭部の棘波ないしは鋭波が 2 例（3\%）
Table 5 Localization of radiological finding

\begin{tabular}{l|c|c|c}
\hline & MRI & CT & total \\
\hline temporal & 2 & 7 & 9 \\
(hippocampal) & $(1)$ & & \\
parietal & 1 & 1 & 2 \\
occipital & 0 & 1 & 1 \\
frontal & 0 & 1 & 1 \\
sidedness (left/right) & $1 / 1$ & $5 / 3$ & $6 / 4$ \\
\hline not particular findings & 13 & 21 & 28 \\
\hline total & 17 & 34 & 45 \\
\hline
\end{tabular}

において認められた。

（5）炎の他の種類のてんかん放電が 4 例（6\%） で認められた。

（6）発作波の側性は左が20例，右が22例でほぼ 同数であった。

（7）てんかん放電が記録されなかったものは20 例 $(28 \%)$ であった。

5. 放射線学的所見 (Table 5)

（1）CTは34例に敃いて行われたが，左右いず れかの大脳半球に病巣の認められたもののらちで は, 側頭葉病変が 7 例, 頭頂 葉病変, 後頭葉病 変, 前頭葉病変がそれぞれ 1 例あった。4例にお いて両側性びまん性の脳萎縮が認められた。病的 所見の認められないものが21例であった。

（2）MRIは17例で行われたが，左右いずれか の大脳半球に病巣の認められたもののらちで, 側 頭葉病変は 2 例, 頭頂葉病変は 1 例あった。

（3）左側に病巣のあった 6 症例の内訳は， 5 例 が側頭部病変で, 萎縮 1 例, 低吸収域 1 例, の5 胞 1 例, MRI での海馬の高信域が 1 例で, 後頭 葉と側頭葉に及ぶ孔脳症状が 1 例, 頭頂葉病巣が 1 例あった。

（4）右側に病巣のあった 4 例は, 2 例がのう胞, 1 例が海馬の萎縮, 1 例が ring enhancement で, いずれも側頭葉に病巣が認められた。

\section{6-1. 自律神経性前兆を持つ患者亡 dysmne-} stic seizure を持つ患者の比較 (Table 6)

（1）AU 群では男性47人・女性36人で男性が多 く, DM 群では男性 26 人, 女性 36 人で女性が多か 
Table 6 Comparison of patients with dysmnestic seizures and autonomic seizure

\begin{tabular}{l|c|c|c}
\hline & autonomic $(\mathrm{n}=83)$ & dysmnestic $(\mathrm{n}=62)$ & - \\
\hline sex $(\mathrm{m} / \mathrm{f})$ & $47 / 36$ & $26 / 36$ & - \\
age & $25.8 \pm 11.3$ & $25.0 \pm 10.5$ & - \\
onset & $12.2 \pm 8.0$ & $15.3 \pm 9.3$ & - \\
MR & 8 & 5 & - \\
possible etiology & 11 & & - \\
perinatal troubles & 8 & 10 & - \\
head trauma & 13 & 7 & - \\
meningo-encephalitis & 4 & 5 & -1 \\
brain tumor & 18 & 4 & - \\
complex febrile seizure & 24 & 24 & - \\
no possible etiology & & & - \\
radiological findings & $33 / 63$ & $24 / 38$ & - \\
not particular findings & $13 / 63$ & $4 / 38$ & - \\
left-sided lesion & $15 / 63$ & $3 / 38$ & \\
right-sided lesion & & 17 & - \\
EEG finding & 23 & 19 & \\
left-sided foci & 28 & & \\
right-sided foci & & & \\
\hline
\end{tabular}

Table 7 Comparison of seizures with dysmnestic seizures and autonomic seizure

\begin{tabular}{l|c|c|c}
\hline & autonomic $(\mathrm{n}=83)$ & dysmnestic $(\mathrm{n}=62)$ & \\
\hline complex partial seizure & $70(84 \%)$ & $44(71 \%)$ & - \\
$\quad$ (oral automatism) & 22 & 15 & - \\
$\quad$ (verbal automatism) & 9 & 8 & - \\
tonic clonic seizure & $50(60 \%)$ & $39(63 \%)$ & - \\
$\quad$ (only during sleep) & $6(7 \%)$ & $8(13 \%)$ & - \\
other auras & 8 & 4 & - \\
unilateral motor & 6 & 6 & - \\
elementary visual & 5 & 5 & - \\
aphasic & 2 & 11 & - \\
anxiety & 0 & 1 & \\
olfactory & 83 & 66 & \\
\hline total & & & \\
\hline
\end{tabular}

ったが，両群間で有意差はなかった。

(2) 問診・検査時の年齢は AU 群で $25.8 \pm 11.3$

歳, DM 群で $25.0 \pm 10.5$ 歳であり, 両者の間に 有意差はなかった。

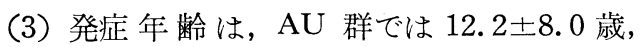
$\mathrm{DM}$ 群では 15.3土9.3歳であり，両者の間には 5 \%の危険率で有意差が認められた。

（4）精神遅滞の合併率は, AU 群で 8 人 (10\%)
で，DM 群では 5 人 $(7 \%)$ であり，両者に有意 差はなかった。

（5）てんかんの原因に関しては，重症複雑熱性 痤攣のみが両者で有意差を持ら, $\mathrm{AU}$ 群に和いて DM 群に和けるよりも有意にその頻度が高かった $\left(\chi^{2}=8.1, \mathrm{p}<0.01\right)$ 。

（6）脳波所見・放射線学的所見においては両者 に有意差はなかった。 
Table 8 Dysmnestic seizues in the literature

\begin{tabular}{|c|c|c|c|c|c|c|}
\hline \multicolumn{2}{|c|}{ author: year } & \multirow{2}{*}{$\begin{array}{l}\text { subjects } \\
733 * 1\end{array}$} & \multicolumn{2}{|c|}{ deja strange } & reminiscence & lateralization $(\mathrm{R} / \mathrm{L})=1$ \\
\hline lund & $: 52$ & & $(34$ & & ) & \\
\hline meyer-M. & $: 53$ & $72 * 2$ & 4 & & & \\
\hline bingley & $: 58$ & $90 * 2$ & $(29$ & \#2 & ) & $017 / 7$ (anatomy) \\
\hline mullan & $: 59$ & $217 * 3$ & 10 & 10 & $-* 3$ & ○/1 (EEG) \\
\hline cole & $: 63$ & $110 * 4$ & 13 & & & $\times 9 / 4$ (anatomy) \\
\hline currie & $: 71$ & $666 * 5$ & 93 & & & \\
\hline king & $: 77$ & $270 * 2$ & 7 & 15 & & \\
\hline sengoku & $: 82$ & $192 * 4$ & 19 & $5 * 4$ & 12 & \\
\hline gupta & $: 83$ & $290 * 6$ & 17 & & & O11/2 (EEG) \\
\hline kanemoto & $: 88$ & $143 * 6$ & 28 & 17 & & $\times 8 / 8(\mathrm{EEG})$ \\
\hline current & $: 92$ & $563 * 7$ & 34 & 29 & 20 & $\times 12 / 8(\mathrm{EEG})$ \\
\hline
\end{tabular}

*1 patients with supratentorial tumor

*2 patients with temporal EEG foci

*3 patients with anterior temporal lobotomy

*4 patients with psychomotor seizures

*5 patients with temporal EEG foci and psychomotor seizures

*6 patients with complex partial seizures

*7 patients with simple partial seizures

"1 Sidedness of EEG foci in patients with deja veçu

* 2 The sum of memory illusions and reminiscence

* 3 Patients with experiential phenomena are excluded from the study

*4 Illusions of depersonalization are included

\section{6-2. 自律神経性前兆を持つ患者と dysmne- stic seizure を持つ患者の 発作症状の 比較 (Table 7)}

（1） AU 群に括いては比較的複雑部分発作を合 併する率が高いのに対して，DM 群では，強直間 代発作，殊に夜間の強直間代発作を合併する率が 高かったが，いずれも有意差には至らなかった。

（2）合併する前兆については，不安発作のみ が，有意に DM 群で多かったが，「後ろに人がい る生々しい感じ」といった実体的意識性に近い不 安感や，「何か大変なことが起こりそうだ」とい ら世界没落体験を思わせる不安感が 11 例中 5 例で 確認された。

\section{考察}

\section{Dysmnestic seizure の出現頻度と側性と} 局在性 (Table 8)

Dreamy stateを扱っている文献から，追想と親 近感の変容を加算して dysmnestic seizure の頻度 を推測することのできる二つの研究は，いずれも
精神運動発作を持った患者を母集団としていた が，両者の頻度は，19\% いた。後者はその母集団に, 脳腫瘍の患者が多い 特徵があった。既知感を題材とすると，精神運動 発作を示す患者 $\left(12 \%{ }^{3)} ; 10 \%{ }^{27)}\right)$ ，側頭葉焦点を 脳波上持つ患者 $\left(6 \%{ }^{22)} ; 3 \%{ }^{19)}\right)$, 複雑部分発作 を示す患者 $\left(20 \%{ }^{18)} ; 6 \%{ }^{9)}\right)$ ，側頭葉焦点と精神 運動発作を持つ患者 $\left(14 \%{ }^{4)}\right)$ など，母集団によ ってばらつきがみられ，精神運動発作を母集団と する報告では，敃扣むね，1割を超える頻度があ ったのに対して，側頭葉焦点を母集団とする報告 では dysmnestic seizure の頻度は 1 割に満たなか った。単純部分発作を示したわれわれの患者中の dysmnestic seizure の頻度は，13\%であった。

Penfield $5^{26)}$ は, 大脳刺激実験に括いて, 劣位 半球の側頭葉の刺激が追想体験をより生じやすい ことを指摘した。臨床発作の統計においては, Cole $ら^{3)}$ と Kanemoto $5^{18)}$ がこの見解に否定的 な結果を, Bingley2), Mullan ら ${ }^{23)}$, Gupta $ら^{99}$ がこの結果に肯定的な結果をそれぞれ提出してい 
るが，今回のわれわれの検討においても劣位半球 焦点を示す患者が多いものの統計的には有意では なかった。Lüdersら ${ }^{20)}$ は, 左半球においては発作 時言語障害のために体験されたことが報告されな い可能性があるのではないかと指摘している。 この問題の決着には深部脳波による dysmnestic seizure の発作時脳波の集積が必要であろう。

側性に関する研究者の意見が一致しないのに対 して, 局在性に関しては, dysmnestic seizure と 側頭部の関連が従来より一致して指摘されてきて 拈り，最近も Palmini ら ${ }^{24)}$ とって確認されてい る。今回のわれわれの放射線学的所見・脳波所見 は, 側頭部焦点括よび側頭部病巣が他の部位と比 較して, dysmnestic seizure を示す症例では压倒 的に多いことを示して扣り，いずれも従来の研究 者の指摘を追認していた。

\section{Dysmnestic seiznre と類縁概念}

Dysmnestic seiure といら述語は, 1981年の国際 分類 ${ }^{5)}$ 以降の比較的新しい用語であり，伝統的に は“dreamy state”と呼ばれてきた状態の一つの 側面を抽出したものと考えることができる。 “Dreamy state”に相当する症状の記載は, 十九 世紀半ばの Herpin ${ }^{11)}$, Quaerens という偽名で 自らの症状を報告した医師 ${ }^{13)}$ に遡るが，当初は， “intellectual aura”といら術語がそれに当てられ ていた。Jackson が, “intellectual aura”の代わ りに, “dreamy state”という術語を採用したの は, “dreamy state” は, 赤や青の火の玉などのよ り要素的な “aura”とは並列的に論ずることが適 当でないからと説明されて扣り ${ }^{13)}$, Jackson は “dreamy state”の本質が意識の病理のらちにある と想定していたことが推測される。少なくとも 1888年の時点では, 彼は, 意識喪失を伴う自動症 の状態も場合によって “dreamy state” に含めて

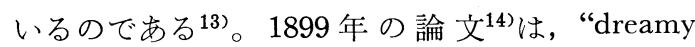
state”に持ける意識の病理の特質をより具体的に 言及することになる。そのなかでは，精神的二重 視 (mental diplopia), すなわち, 見当識が保持 されたまま自己の周用の世界に対する認知の仕方 が変容する 状態が “dreamy state” の特質として 取り出されている14)。Penfield ${ }^{25,26) の ~ “ d r e a m y ~}$ state” は, 自動症と幻覚体験（体験現象：exper- iential phenomenon) と錯覚体験（解釈現象： interpretative phenomenon)から成り立っており， その範囲は, 1888年の Jackson の考えとほぼ一致 している。Jackson が, “dreamy state” の本質を 意識の二重化の内に置いたのに対して, Janz ${ }^{15)}$ は, 親近感の変容 (Vertrautheitsveränderung) こ そ, “dreamy state” の必須の条件であると考元 た。Janz のいら意味での親近感の変容は, 例え ば体の一部が大きくなるように感じられるといっ た身体感覚の変化をも含んで打り, dysmnestic seizure の一部と見なすことの可能な Penfield の “illusion of familiarity”より広い概念となってい る。Gloor ${ }^{7,8)}$ は意識という曖昧な概念をその出自 に持つ“dreamy state”といら述語を排し, Penfield の体験現象 “expeeriential phenomena” の概念を 拡張して, “dreamy state”に相当する症状全体を 表現する述語として採用した。Jackson が “crude sensation” と対比した “elaborate sensation"12) に 当たるような前兆体験は, ほとんどの場合, 別の 種類の前兆体験と跨がって扣り，それに境界線を 引くことは常に一定の操作性を伴うが28), 記憶障 害の陽性症状としての “dysmnestic seizure” は, “intellectual aura”から Gloor の “experiential phenomena”に至る一連の症状の中核的な側面の 一つを代表していると考えられる。

\section{3. 不安発作と dysmnestic seizure}

今回の検討に拈いては, AU 群と比較して, DM 群に打いて, 不安発作の合併率が有意に高か った。しかも, この場合, DM 群に拈いては, 「後ろにあたかも人がいるかのようで，襲われそ らだ」といった実体的意識性に近い意識の変容を 伴う不安発作が 3 分の 2 を占めていた。

不安発作が, 側頭葉てんかんの一症状として出 現することは良く知られているが10,30), 発作症状 としての不安発作は, dysmnestic seizure よりも むしろ自律神経性前兆との関連に和いて論じられ ることが多かった10,29)。しかし，われわれの検討 では, 数に打いて勝る AU 群よりも, 数のより少 ない DM 群に拈ける方が不安発作の合併率は高 く, 不安発作は, dysmnestic seizure とょり親和 性が高いことが統計的有意差を持って示された。 不安感と既知感と上腹部不快感は, いずれも, 側 
頭葉内側部を起源とする発作において頻繁に出現 する前兆であるが，情動発作が，自律神経性前兆 ではなく，記憶の錯覚とより密接な繫がりがある ことは, 情動の成り立ちを考える上で示唆に富む 所見であると思われた。

\section{4. 発症年齢と HHE 症候群}

Taylor ら $^{28)}$ は, 早期発症の側頭葉てんかんにお いて Jackson のいう “crude sensation” が出現し 易いことを指摘したが, “intellectual aura”と “crude sensation”を比較したともいえる今回の検 討において，われわれは Taylor らの主張を支持 する所見を得た。Dysmnestic seizure のような複 雑な訴えは，いうまでもなく，一定の知能と年齢 に達しなければ表出することができないことは明 らかである。しかし，今回の検討に拈いては， $\mathrm{AU}$ 群と DM 群間に問診時の年齢差はなく, ま た，精神遅滞のある患者の占める割合にも有意差 はなかった。すなわち, 両群間の差異を患者個人 の表現能力の差異に帰することは困難であり, 両 者の発症年齢の差異はより生理学的な基盤に基づ くものであると推測される。

われわれは以前本誌上に怙いて, HHE 症候群 に拈ける前兆が, 対照群と比較して自律神経性前

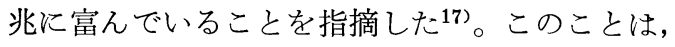
Gastaut $ら^{6)}$ の最初の指摘以降, 汪とんど注目を 浴びてこなかったが，今回のわれわれの検討は， HHE 症候群を呈するような重症熱性痤攣を既往 歴に持つてんかん発作は, “intellectual aura”ょ りも“crude sensation”とより親和性を持つこと を再確認したといえる。

\section{文献}

1) Bergson, H. (1896) Matière et mémoire. Alcan, Paris.

2) Bingley, T. (1958) Mental symptoms in tempoal lobe epilepsy and temporal lobe gliomas. Acta Psychiatr Neurol Scand (Suppl) 120.

3) Cole, M., Zangwill, O.L. (1963) Déjà vuin temporal lobe epilepsy. J Neurol Neurosurg Psychiatry 26, 37-38.

4) Currie, S.H., Heathfield, K.W.G., Henson, R.A., Scott, D.F. (1971) Clinical course and prognosis of temporal lobe epilepsy-survey of 666 patients. Brain 94, 173-190.
5) Dreifuss, F.E. (1981) Proposal for revised clinical and electroencephalographic classification of epileptic seizures. Epilepsia 22, 489-501.

6) Gastaut, H., Poirier, F., Payan, H., Salamon, G., Toga, M., Vigouroux, M. (1959/60) H.H.E. syndrome-hemiconvulsions, hemiplegia, epilepsy. Epilepsia 1, 418-447.

7) Gloor, P., Olivier, A., Quesney, L.F., Andermann, F., Horowitz, S. (1982) The role of the limbic system in experiential phenomena of temporal lobe epilepsy. Ann Neurol 12, 129144.

8) Gloor, P. (1990) Experiential phenomena of temporal lobe epilepsy. Brain 113, 1673-1694.

9) Gupta A.K., Jeavons, P.M., Hughes, R.C., Covains, A. (1986) Aura in temporal lobe epilepsy: clinical and electroencephalographic correlation. J Neurol Neurosurg Psychiatry 46, 1079-1083.

10) Henriksen, G.F. (1973) Status epilepticus partialis with fear as clinical expression. Report of a case and ictal EEG findings. Epilepsia 14, 39-46.

11) Herpin, Th. (1867) Des Accés Incomplets d'Epilepsie. Bailliére, Paris

12) Jackson, J.H. (1880/81) On right and left-sided spasm at the onset of epileptic paroxysms, and on crude sensation warning, and elaborate mental states. Brain 3, 192-206.

13) Jackson, J.H. (1888) On a partilcular variety of epilepsy ('intellectual aura'), one case with symptoms of organic brain disease. Brainn 11, 179-207.

14) Jackson, J.H., Stewart, P. (1899) Epileptic attacks with a warning of a crude sensation of smell and with the intellectual aura (dreamy state) in a patient who had symptoms pointing to gross organic disease of right temorosphenoidal lobe. Brain 22, 534-549.

15) Janz, D. (1969) Die Epilepsien. Thieme. Stuttgart.

16）兼本浩祐（1990）虹様幻視と既知感を段階的に前 兆として示した migraine-epilepsy syndrome の 1 例。神経内科 33, 244-246.

17) 兼本浩祐, 扇谷 明, 金沢 治, 河合逸雄(1990) HHE 症候群一その病態形成的側面と前兆の組成 を中心として一. てんかん研究 8，39-45.

18) Kanemoto, K., Janz, D. (1989) The temporal sequence of aura-sensations in patients with complex focal seizures. J Neurol Neurosurg Psy- 
chiatry 52, 52-56.

19) King, D.W., Ajmonemarsan, C.A.(1977) Clinical features and ictal patterns in epileptic patients with EEG tempoal lobe foci. Ann Neuol 2, 138-147.

20) Lüders, H., Lesser, R.P. (1989) Epilepsy-Electroclinical syndromes-, Springer, Berlin.

21) Lund, M. (1952) Epilepsy in association with intracranial tumor. Acta Psychiat Scand(Suppl) 18 (cited in Bingley).

22) Meyer-Mickeleit, R.W. (1953) Die Dämmeratacken als charakteristischer Anfallstyp der temporal Epilepsie (psychomotorische Anfälle, Äquivalente, Automatismen). Nervenarzt 24, 331-346.

23) Mullan, S., Penfield, W. (1959) Illusion of comparative interpretation and emotion. Arch Neurol Psychiatr (Chicago) 81, 269-284.

24) Palmini, A., Gloor, P. (1992) The localizing value of auras in patial seizures: a prospective and retrospective study. Neurology 42, 801-808,
25) Penfield, W., Jasper, H. (1954) Epilepsy and functional anatomy of the human brain. LittleBrown, Boston.

26) Penfield, W., Perot, P. (1963) The brain's record of auditory and visual experience. Brain 86, 595-696.

27) 扇谷 明, 清野昌一, 河合逸雄 (1987) Temporal lobe epilepsy: origin and significance of simple and complex auras. J Neurol Neurosurg Psychiatry 50, 673-681.

28) Taylor, D., Lochery, M. (1987) Tempoal lobe epilepsy: origin and significance of simple and complex auras. J Neurol Neurosurg Psychiatry 50, 673-681.

29) Weber, W.C., Jung, C.R. (1940) Utber die epileptische Aura. Z Ges Neurol Psychiatr 170, 211-265.

30) Williams, D. (1959) The structure of emotions reflected in epileptic experiences. Brain 79, 2967.

\section{Summary}

\section{Dysmnestic Seizures-A Special Attention to the Comparison with Patients suffering from Autonomic Seizures}

Kousuke Kanemoto, Ken Mayahara, Hirokazu Yamada, Itsuo Kawai

Patients with dysmnesticc seizures were examined clinically. They were selected from five hundreds and sixty-three ambulatory patients with simple partial seizures. The dysmnestic seizures consisted of thirty-four cases of deja veçu, twenty nine cases of derealizations (inclusive of depersonalizations), twenty cases of reminiscences.

In oder to elucidate clinical features of patients with dysmnestic seizure, we compared cases of dysmnestic seizures without autonomic seizures (DM group) with cases of autonomic seizures without dysmnestic seizures (AU group). As a result, the following points were statistically confirmed: DM group had higher age at onset; higher rate of anxiety aura; lower rate of severe complex febrile convulsion.

Interrelations between concepts related to the dysmnestic seizure such as intellectual aura, dreamy state and experiential phenomena by Gloor were discussed.

J. Jpn. Epil. Soc. $1993 ; 11$ : 101-109

(received: September 11, 1992, 1st revised: November 16, 1992, 2nd revised: December 2, 1992, accepted: December 3, 1992) 